\title{
Endocannabinoid Regulation of Reward and Reinforcement through Interaction with Dopamine and Endogenous Opioid Signaling
}

\author{
JM Wenzel ${ }^{1}$ and JF Cheer*,1,2,3 \\ ${ }^{1}$ Department of Anatomy and Neurobiology, University of Maryland School of Medicine, Baltimore, MD, USA; ${ }^{2}$ Department of \\ Psychiatry, University of Maryland School of Medicine, Baltimore, MD, USA; ${ }^{3}$ Program in Neuroscience, University of Maryland \\ School of Medicine, Baltimore, MD, USA
}

\begin{abstract}
The endocannabinoid system (eCB) is implicated in the mediation of both reward and reinforcement. This is evidenced by the ability of exogenous cannabinoid drugs to produce hedonia and maintain self-administration in both human and animal subjects. eCBs similarly facilitate behaviors motivated by reward through interaction with the mesolimbic dopamine (DA) and endogenous opioid systems. Indeed, eCB signaling in the ventral tegmental area stimulates activation of midbrain DA cells and promotes DA release in terminal regions such as the nucleus accumbens (NAc). DA transmission mediates several aspects of reinforced behavior, such as motivation, incentive salience, and cost-benefit calculations. However, much research suggests that endogenous opioid signaling underlies the hedonic aspects of reward. eCBs and their receptors functionally interact with opioid systems within the NAc to support reward, most likely through augmenting DA release. This review explores the interaction of these systems as it relates to reward and reinforcement and examines current literature regarding their role in food reward.

Neuropsychopharmacology Reviews (2018) 43, 103-115; doi:I0.1038/npp.2017.126; published online 9 August 2017
\end{abstract}

\section{INTRODUCTION}

Organisms are motivated to seek pleasurable experiences (eg, food, sex, drugs of abuse) and receipt of these positive/ rewarding stimuli reinforce behavior. As such, neuroscientists have sought to identify the neural underpinnings of reward and reinforcement for decades. In the 1950s Olds and Milner (1954) observed the first instance of brain stimulation reward (BSR), and subsequently determined that rats would work for this stimulation-that is, electrical current delivered to a discrete brain region could serve as a positive reinforcer. These findings spurred the search for the brain's 'reward center'. Since then, numerous nuclei and neurotransmitter systems have been implicated in reward processing and reinforcement, however, none so much as the mesolimbic dopamine (DA) system (Ikemoto, 2007; Taber et al, 2012; Wise and Rompre, 1989). An established body of evidence shows that natural reinforcers such as food, as well as drugs of abuse and BSR support operant behaviors through their

${ }^{*}$ Correspondence: Dr JF Cheer, Department of Anatomy and Neurobiology, Department of Psychiatry, Graduate Program in Neuroscience, University of Maryland School of Medicine, HSF I, Room 280J, 20 Penn Street, Baltimore, MD 21201, USA, Tel: +1 410 7060112, Fax: +1 410 7062512, E-mail: jcheer@som.umaryland.edu

Received 19 April 2017; revised 1 June 2017; accepted 8 June 2017; accepted article preview online 27 June 2017 ability to activate the mesolimbic system (Di Chiara et al, 2004; Hernandez and Hoebel, 1988a,b; Yoshida et al, 1992). Moreover, DAergic lesions or receptor antagonism attenuate approach toward, or responding for these stimuli (Ettenberg and Camp, 1986a,b; Mora et al, 1975; Robledo et al, 1992).

Accumulating evidence from the last few decades, however, re-focused DA's role in reward. Indeed, while research suggests that DA controls several aspects of reinforcement, such as motivation (Salamone and Correa, 2002), incentive salience (Berridge and Robinson, 1998), and prediction error (Schultz et al, 1997), the pleasurable experience produced by rewarding stimuli (ie, hedonia) does not appear to be strictly DAdependent. In support of this view, DA depletion spares orofacial 'liking' responses to sweet tasting solutions in rats (Berridge and Robinson, 1998), and DA receptor antagonism in human subjects does not reduce reported ratings of pleasure produced by food or drugs (Brauer and De Wit, 1997; Meyers et al, 2010). Rather, research suggests that the subjective effects of pleasure that characterize 'reward' stem from activation of the endogenous opioid system. Indeed, opioid receptor agonism enhances orofacial liking responses to sweet solutions in rats (Pecina, 2005), and human studies report that systemic opioid antagonism attenuates the experience of pleasure following physical activity (Daniel et al, 1992) or food consumption (Yeomans and Gray, 1996). Nevertheless, the neurobiology underlying these effects remains complicated, 
since opioid and DA systems are anatomically connected and blockade of opioid signaling also reduces DAergic activity (Spanagel et al, 1992; Taber et al, 1998).

Interestingly, both DAergic and opioid systems are highly influenced by endocannabinoid (eCB) signaling and mounting evidence indicates that the $\mathrm{eCB}$ system is critical in DAergic and opioid control of reinforcement and reward. This review will explore the relationship of these neural systems as they relate to reward and reinforcement produced by exogenous and endogenous CBs, BSR, and food. We will attempt to differentiate between aspects of reward and reinforcement when possible, however, in animal behavioral tests these properties can be difficult to deconvolve. In general, we will explore reward as it pertains to hedonia or pleasure. BSR and place conditioning are the most widely used paradigms to assess reward, so we will focus on results from these models. Stimuli described here as rewards decrease thresholds for BSR and induce conditioned place preferences (CPPs) (Fountain et al, 1990; Tzschentke, 2007). Reinforcement, however, is a separate, albeit usually interconnected, process from reward. We will discuss reinforcement as it relates to the ability of a stimulus to reinforce or support operant behavior. Self-administration paradigms are considered optimal for measuring drug reinforcement, while operant responding for natural stimuli, such as food, is utilized to assess their reinforcing value. These distinctions are important to recognize as not all rewards are capable of promoting operant behavior and not all reinforcers produce hedonia, evidencing that these processes are likely subserved by different brain systems.

\section{THE eCB SYSTEM IN BRIEF}

The eCB system is so-named because it provides the binding site for exogenous CBs (chemical constituents of the cannabis plant or their synthetic analogs). This neuromodulatory system consists of two well-characterized cannabinoid (CB) receptors (CB1 and CB2), as well as their endogenous ligands and ligand-related synthesis, reuptake, and degradation proteins. Both $\mathrm{CB} 1$ and $\mathrm{CB} 2$ are $\mathrm{G}_{\mathrm{i} / \mathrm{o}^{-}}$ coupled, however, they differ in both anatomical distribution and function. While CB1 is expressed predominately in the central and peripheral nervous system (Herkenham et al, 1991), traditionally, CB2 is found mainly in peripheral and brain immune cells (Galiègue et al, 1995; Núñez et al, 2004). However, recent evidence suggests that CB2 is also expressed in neurons and glial cells (Gong et al, 2006; Xi et al, 2011), although CB2 receptors are less widely expressed than CB1 and have much lower levels of expression (Atwood and Mackie, 2010). Interestingly, CB1 receptors are located primarily on presynaptic terminals of glutamate and GABA cells where ligand binding results in decreased neurotransmitter release (Katona et al, 1999), whereas CB2 is mainly expressed on post-synaptic sites and ligand binding hyperpolarizes the post-synaptic membrane (Zhang et al, 2014). Despite the identification of neuronal CB2 receptors, studies on their function have been controversial due to a lack of selective CB2 antibodies and knockout models, as well as CB1/CB2 heterodimerization (see review by Chen et al (2017). Because of these reasons, much less information is available regarding the role of $\mathrm{CB} 2$ receptors in reward/ reinforcement, but see Zhang et al (2014). It should also be noted that, although this review will focus on effects at CB1 receptors, eCBs also bind to various ligand-gated ion channels and other G-protein coupled receptors (Ryberg et al, 2009; Szallasi and Di Marzo, 2000).

The primary endogenous ligands of $\mathrm{CB}$ receptors are $\mathrm{N}$-arachidonylethanolamine (anandamide; AEA), a partial agonist at $\mathrm{CB} 1$ receptors, and 2-arachidonylglycerol (2-AG), a full agonist at both CB1 and CB2 receptors (Devane et al, 1992; Mechoulam et al, 1995). These eCBs are synthesized by neurons 'on-demand' following $\mathrm{G}_{\mathrm{q} / 11}$-coupled receptor binding, or heightened cell activation resulting in an influx of $\mathrm{Ca}^{2+}$. Upon synthesis, these lipid messengers readily diffuse through the post-synaptic membrane and interact with $\mathrm{CB}$ receptors of nearby cells. Thus, brain eCBs primarily act as retrograde messengers, transmitting messages from post- to pre-synaptic neurons, resulting in negative feedback to presynaptic cells (Alger, 2002). Following release, AEA and 2-AG signaling is quickly terminated through cellular reuptake and hydrolysis by the enzymes fatty acid amide hydrolase (FAAH) and monoacylglycerol lipase, respectively (FAAH can also hydrolyze 2-AG). Although other eCBs have been identified, AEA and 2-AG remain the most wellstudied.

\section{THE MESOLIMBIC DA SYSTEM}

The mesolimbic DA system is composed of DAergic cell bodies of the ventral tegmental area (VTA) that send their diffuse projections to cortical and limbic regions, including the nucleus accumbens (NAc), a region heavily implicated in reward and reinforcement (Swanson, 1982). Midbrain DA neurons are believed to signal reward-related stimuli through changes in their firing patterns. In general, these neurons fire in a tonic low-frequency $(1-5 \mathrm{~Hz})$ pacemaker manner, which results in a baseline DAergic 'tone' on high-affinity D2-like DA receptors (Grace, 1991). However, the presentation of rewarding/reinforcing stimuli is accompanied by phasic high-frequency burst firing $(\geqslant 20 \mathrm{~Hz})$, (Grace, 1991), increasing terminal DA sufficiently to occupy low-affinity excitatory D1-like receptors (Dreyer et al, 2010). Not to intentionally over-simplify their function, these cells also transiently burst fire to environmental stimuli with no apparent affective valence (Horvitz, 2000), and in some cases in response to aversive events/stimuli (Budygin et al, 2012). Indeed, Brischoux et al (2009) found that although a majority of midbrain DA cells are inhibited by or show no response to aversive stimuli, a subset of VTA DAergic cells are excited by the delivery of electrical shock to the hindpaw. However, these animals, similar to a number of other studies examining DA neuron response to aversive stimuli (Mantz 
et al, 1989; Schultz and Romo, 1987; Ungless et al, 2010), were unfortunately tested under anesthesia, which may have affected the nature of the electrophysiological response. Regardless, these findings provide evidence for two functional DA systems within the VTA-one system responsible for reward-related signals, and another theorized to be activated by all salient stimuli, regardless of valence (Bromberg-Martin et al, 2010; Ikemoto, 2007; Lammel et al, 2011; Redgrave et al, 1999).

Reward-related burst firing of midbrain DA cells occurs in a pattern consistent with 'reward prediction'. That is to say that presentation of hedonic/rewarding stimuli ('rewards') cause burst firing of VTA DA neurons and with repeated stimulus presentation this phasic DA signal shifts from reward receipt to the presentation of reward-predictive cues (Romo and Schultz, 1990). When the probability of reward delivery is high, the magnitude of burst activity is greater to the rewardpredictive cues, but when the probability of reward is low, DAergic cell activity is greater during reward receipt. This suggests that midbrain DA neurons signal an error term reflecting the difference in value of 'expected' $v s$ 'received' rewards-ie, a reward prediction error (Romo and Schultz, 1990). Conversely, reward omission or aversive stimuli cause midbrain DA neurons to pause transient activity, resulting in a negative prediction error (Schultz, 1998). Thus, midbrain DAergic phasic signaling transmits information about previous and current reward situations making this form of signaling particularly important for making cost-benefit analyses in the development of reinforced behaviors.

The functional consequence of midbrain DA cell activation is DA release at terminal regions. Microdialysis studies outline a clear correlation between presentation of positive/ rewarding stimuli and DA release. For example, DA levels are elevated in the NAc following the delivery of food (Hernandez and Hoebel, 1988b), water (Yoshida et al, 1992), or drugs of abuse (Church et al, 1987). Utilizing fast-scan cyclic voltammetry (FSCV), studies show that stimuli known to make VTA DA cells burst fire, ie, food or food-predictive cues, enhance transient DA concentration within the NAc (Roitman, 2004). A wide body of FSCV data similarly supports a role for reward-evoked striatal DA release as a prediction error signal. In support of this, unexpected reward delivery or presentation of reward-predictive cues results in phasic DA release (Brown et al, 2011; Cheer et al, 2007; Roitman, 2004; Sunsay and Rebec, 2008), and omission of an expected reward or presentation of an aversive stimulus results in decreased extracellular DA in the ventral striatum (Gentry et al, 2016; Oleson et al, 2012; Roitman et al, 2008).

Burst firing of DA neurons requires glutamatergic input (Charlety et al, 1991), and conversely, GABAergic input to midbrain DA neurons dampens burst firing and returns the cell to baseline activity (Engberg et al, 1993). Therefore, DAergic response to rewarding stimuli requires orchestration of glutamatergic and GABAergic inputs to the ventral midbrain - the eCB system is uniquely positioned to serve this function.

\section{ECB MODULATION OF DA TRANSMISSION}

The administration of exogenous CBs, such as $\Delta^{9}$-tetrahydrocannabinol (THC), the primary psychoactive constituent of the cannabis plant, elevates extracellular DA concentrations in the ventral striatum (Cheer et al, 2004; Chen et al, 1990; Tanda et al, 1997). This DAergic enhancement is dependent on CB1 receptor activation, as pretreatment with the CB1 antagonist/inverse agonist SR141716A (rimonabant) blocks this effect (Tanda et al, 1997). Single-unit recording studies show that CBs enhance extracellular DA concentrations in the NAc through increasing both the baseline firing rate and burst frequency of midbrain DA neurons (French et al, 1997) in a CB1-dependent manner (Gessa et al, 1998). Interestingly, recent evidence suggests that eCBs, such as 2-AG, can also enhance DA neuron excitability through direct interaction with ion channels (Gantz and Bean, 2017). Additional research is required to determine to what extent this mechanism of action is recruited in vivo and how it influences reward and reinforcement.

Midbrain DA neurons do not express $\mathrm{CB} 1$ receptors, suggesting that CBs must excite VTA DA cells indirectly. The VTA is largely composed of DA neurons ( 60\%; (Swanson, 1982)), a small population of GABA cells (30\%), and even fewer glutamate neurons ( 3\%) (Dobi et al, 2010). The VTA also receives glutamatergic and GABAergic afferents from several limbic and sensory regions. These inputs to DA cells express $\mathrm{CB} 1$, therefore, presynaptic eCB modulation can alter VTA DA cell activity (Melis et al, 2004; Riegel and Lupica, 2004). In vitro administration of the $\mathrm{GABA}_{\mathrm{A}}$ receptor antagonist bicuculine causes VTA DA neurons to burst fire, suggesting that relief of tonic GABA inhibition on VTA DA cells facilitates phasic activation (Cheer et al, 2000). Further, the synthetic CB1/CB2 agonist WIN 55,212-2 (WIN) reduces electrically evoked $\mathrm{GABA}_{\mathrm{A}}$-mediated inhibitory postsynaptic currents of DA neurons in VTA slices, and these effects are blocked by rimonabant (Szabo et al, 2002). Thus, enhanced activation of VTA DA neurons likely promotes synthesis and 'on demand' release of eCBs from DA neurons. These lipophilic messengers then diffuse out of the postsynaptic cell to influence presynaptic inputs, with inhibition of local GABA neurons causing disinhibition of DA cells. Indeed, IPSCs mediated by GABA receptors on VTA DA neurons are inhibited by presynaptic CB1 signaling (Lupica and Riegel, 2005; Riegel and Lupica, 2004). Additionally, activation of CB1 receptors on GABA terminals within the NAc augments local DA terminal release (Sperlágh et al, 2009) to influence reward-related behavior. Alternatively glutamatergic and cholinergic cells of the NAc also express CB1, and binding may decrease NAc DA concentration (Fusco et al, 2004). See Figure 1.

\section{ENDOGENOUS OPIOIDS AND REWARD}

Just like the mesolimbic DA system, endogenous opioid signaling is similarly implicated in reward. The opioid system owes its name to its ability to bind opioids, including, 
opiates derived of the opium poppy (eg, morphine), as well synthetic derivatives like heroin. Opioids exert their characteristic effects (eg, analgesia, respiratory depression, euphoria) through binding to three principle classes of opioid GPCRs $\left(\mathrm{G}_{\mathrm{i} / \mathrm{o}}\right)$ - the mu opioid receptor (MOPR), delta opioid receptor (DOPR), and the kappa opioid receptor (KOPR). The MOPR, DOPR, and KOPR are chiefly activated by three groups of endogenous opioid peptides in a semispecific manner; endorphins which primarily bind to MOPRs, enkephalins which preferentially bind to DOPRs, and dynorphins which typically bind to KOPRs. A fourth opioid receptor has more recently been identified, the nociceptin receptor (NOPR). The NOPR has little affinity for classic opioid peptides, but rather is bound by the peptide Orphanin FQ/nociception. Altogether, these proteins and their receptors are expressed widely throughout the brain, including reward-related regions, such as the VTA and NAc. In general, administration of MOPR, and in some cases DOPR, agonists produce reward and support operant behaviors (see reviews by Le Merrer et al, 2009; Shippenberg et al, 2008). However, KOPR and NOPR are involved in counter-reward mechanisms. Indeed, KOPR agonist administration induces aversion, and while NOPR agonism is not inherently aversive, stimulation of NOPRs opposes the rewarding action of opioids and other drugs of abuse (Chefer et al, 2013; Di Giannuario and Pieretti, 2000). These effects are likely due to the ability of KOPR and NOPR agonists to inhibit mesolimbic DA (for more in-depth analysis, see Lalanne et al (2014); Witkin et al (2014). This review will focus mainly on opioid action at MOPRs, given their primary role in reward-related processes. Indeed, MOPR agonists, including morphine and endorphins, are readily self-administered by animals (Bozarth and Wise, 1981; Thompson and Schuster, 1964) and their administration supports CPP (Hnasko et al, 2005) and decreases thresholds for BSR (van Wolfswinkel and van Ree, 1985).

\section{MOPR AGONISTS ENHANCE DAergic ACTIVITY}

Systemic or intra-VTA MOPR agonism increases the firing rate of VTA DA neurons (Melis et al, 2000), and enhances DA release in the NAc (Spanagel et al, 1992), suggesting that MOPR agonists influence reward and reinforcement through activation of the mesolimbic system. In support of these findings, several studies have shown that DA antagonists block CPP for opioids (Acquas and Di Chiara, 1994; Bozarth and Wise, 1981; Leone and Di Chiara, 1987). MOPRs are located both pre- and post-synaptically within VTA and NAc and ligand binding results in inhibition of neurotransmitter release and membrane hyperpolarization (Fields and Margolis, 2015). Therefore, similarly to eCBs, it is likely that within the VTA, MOPR agonists disinhibit DA cells through inhibition of GABA release. Indeed, the selective MOPR agonist DAMGO inhibits presynaptic GABAergic inputs on VTA DA neurons (Zhang et al, 2015). However, recent evidence demonstrates that MOPR activation also disinhibits glutamatergic input to VTA DA cells via presynaptic GABA inhibition, suggesting that disinhibition of presynaptic glutamate release similarly works to enhance VTA DA neuron activity (Chen et al, 2015) (Figure 1a). Striatal DA release can also occur independently of VTA DA cell body excitation. Indeed, the VTA also sends GABAergic projections to the NAc, which synapse of cholinergic interneurons, inhibiting their excitatory input onto DA terminals (Figure 1b). Thus, opioid inhibition of VTA GABA cells functionally disinhibits striatal cholinergic neurons to augment NAc DA release independent of DA firing (Fields and Margolis, 2015). However, whether and to what extent this occurs in vivo remains unknown, and recent studies show that MOPR agonists can bind directly to cholinergic interneurons thereby reducing NAc terminal DA release (Yorgason et al, 2017). Additionally, the mechanism by which endogenous opioid peptides exert their effects as well as the precise time course of their actions in the mesolimbic system remains unclear, as the literature to date has relied solely on the application of exogenous compounds. Future research should employ opto- and chemo-genetic techniques to examine the role of opioid systems in reward and reinforcement.

Interestingly, behavioral evidence suggests that opioids can exert rewarding/reinforcing effects independent of DA function. For example, Ettenberg et al (1982) found that systemic DA antagonism with low doses of the DA receptor antagonist alpha-flupenthixol enhanced cocaine self-administration, but did not affect self-administration of heroin, while high doses abolished self-administration of cocaine, but not heroin (Ettenberg et al, 1982). Furthermore, DAdeficient mice still acquire CPP for morphine (Hnasko et al, 2005), although at higher doses than those employed in other studies. While the mechanisms underlying DA-independent opioid reward remain unclear, Laviolette et al (2002) showed that intra-NAc DA receptor antagonism blocked morphine CPP in dependent, but not naive, rats. This suggests that opioid reward may shift between DA-dependent and DA-independent mechanisms conditional to an organism's motivational state. However, the neural underpinnings of this phenomenon remain unknown.

\section{EXOGENOUS CBS AND REWARD}

A wide body of literature demonstrates the powerful rewarding and reinforcing properties of exogenous CBs in human subjects. However, the animal literature presents a complicated picture. While some studies suggest that $\mathrm{CB}$ administration does not affect (Arnold et al, 2001) or attenuates BSR (Vlachou et al, 2005), others report that low doses of THC reduce BSR thresholds (Lepore et al, 1996). A report by Katsidoni et al (2013) indicates biphasic effects of THC on BSR dependent on dose, with a low dose of THC decreasing BSR thresholds and a higher dose increasing them. Both effects were reversed by pretreatment with 
rimonabant, suggesting that $\mathrm{CB} 1$ receptor signaling is required for these dose-dependent rewarding and aversive actions of THC. Similar discrepancies exist in the CB CPP literature. Indeed, while some studies report $\mathrm{THC}$-induced CPP in rodents (Valjent and Maldonado, 2000), other studies report CB-induced conditioned place aversion (CPA) (Parker and Gillies, 1995; Cheer et al, 2000). It is has been hypothesized that this discrepancy is also dose-dependent, with time of injection playing a major role (Gardner, 2005). Lepore et al (1995) found that when THC CPP pairings were $24 \mathrm{~h}$ apart, only higher doses of THC produced CPP, however, when THC pairings were $48 \mathrm{~h}$ apart, lower doses of THC produced CPP and higher THC doses produced CPA. The authors explain this difference as an effect of THC withdrawal-induced dysphoria. That is, when THC pairings occur at 24-hour intervals, they coincide with withdrawal produced by the previous THC administration, and thusly a higher dose of THC is required to overcome withdrawal effects and produce reward. However, when pairings occur at $48 \mathrm{~h}$ intervals they do not overlap with THC withdrawal, allowing the lower doses to produce reward and causing higher doses to produce aversion (Gardner, 2005). Lepore et al cite unpublished observations of acute THC withdrawal-induced increases in BSR thresholds as evidence for their conclusions, however, peer-reviewed data demonstrating this phenomenon is lacking. Other studies indicate that pre-exposing an animal to THC in its home cage before place conditioning promotes the development of $\mathrm{CB}$ $\mathrm{CPP}$, purportedly through attenuation of the unconditioned aversive effects of these drugs (Valjent and Maldonado, 2000). Thus, with consideration to dose and timing of injection, animal models reveal rewarding properties of CB drugs.

\section{eCBs AND REWARD}

Studies examining the rewarding properties of eCBs, however, are much less clear. Blockade of eCB signaling with rimonabant is reported to increase BSR thresholds (Deroche-Gamonet et al, 2001) or to produce no change (Arnold et al, 2001; Oleson et al, 2012). Potential rewarding effects of rimonabant may arise due to inverse agonism at $\mathrm{CB} 1$ receptors. Indeed a recent report suggests that systemic administration of the CB1 neutral antagonists AM4113 and PIMSR1 have no effect on BSR (Gardner et al, 2016). Therefore, eCB signaling is not necessary for BSR. Additionally, inhibition of AEA degradation with the FAAH inhibitor URB597, does not enhance BSR (Vlachou et al, 2006). Similarly, FAAH inhibition, does not result in CPP (Gobbi et al, 2005), nor does administration of exogenous AEA (Mallet and Beninger, 1998). However, rimonabant delivered directly into the NAc, but not the dorsal striatum, supports CPP. This again may also be due to rimonabant's action as an inverse agonist, as CPP was abolished by blockade of AMPA glutamate receptors (Ramiro-Fuentes et al, 2010). Altogether, more research, particularly utilizing neutral CB1 antagonists, is necessary to determine the role of eCB signaling in reward.

\section{THE eCB SYSTEM AND REINFORCEMENT}

Similar to studies on $\mathrm{CB}$ reward, examination of $\mathrm{CB}$ reinforcement using self-administration has yielded mixed results. A number of early studies showed that IV THC was not self-administered by rats or rhesus monkeys, but was successfully self-administered by squirrel monkeys (Justinova et al, 2003; Tanda et al, 2000); but see review by Tanda (2016)). Importantly, THC self-administration in squirrel monkeys was blocked by rimonabant (Tanda et al, 2000), evidencing a CB1-dependent mechanism. A number of factors could contribute to a lack of THC self-administration in animal models, among which include discrepancies in the route of administration (humans typically smoke cannabis while animal models rely on IV delivery of drug solutions) and the chemical constituents of the drug (cannabis smoke contains hundreds of $\mathrm{CB}$ and non-CB chemical entities, while animals are typically given access to one $\mathrm{CB}$ compound in isolation). Additionally, CBs may produce locomotor and working memory side effects at higher doses, which could confound task performance. Furthermore, as discussed above, THC's initial aversive/anxiogenic effects may punish rather than reinforce self-administration. Indeed rats readily learned to self-administer THC directly into the VTA or the NAc, presumably because this route of administration bypasses its mechanism of aversive action (Zangen, 2006). Melis et al (2017) recently showed that pre-exposure to vapor containing a 10:1 ratio of $\mathrm{THC}$ and another chemical constituent of cannabis, cannabidiol (CBD), facilitates self-administration of THC+CBD in rats. This may be due to the ability of CBD to alleviate the aversive effects of THC (Russo and Guy, 2006). Alternatively, several groups report IV self-administration of synthetic CBs (eg, WIN and JWH018) in rodents, and selfadministration is blocked by CB1 receptor antagonism (De Luca et al, 2015; Fattore et al, 2001; Lefever et al, 2014; Martellotta et al, 1998). Interestingly, the eCB 2-AG supports self-administration in both rodents and squirrel monkeys, and squirrel monkeys also readily self-administer AEA (De Luca et al, 2014; Justinova et al, 2005, 2011). These effects are blocked by pretreatment with rimonabant. Finally, the AEA transport inhibitor AM404 is self-administered by squirrel monkeys in a CB1 receptor-dependent manner, suggesting that endogenously released AEA is reinforcing (Schindler et al, 2016). Therefore, stimulation of CB1 receptors with either exogenous or endogenous CBs serves as a reinforcer in animal models.

\section{INTERACTION BETWEEN ECB AND OPIOID SYSTEMS}

The eCB and endogenous opioid systems share similar pharmacological characteristics. For instance, CB1 and MOPR are both Gi/o-coupled receptors, and ligand binding leads to inhibition of adenylyl cyclase and voltage-gated calcium channels, and activation of potassium channels and mitogen-activated protein kinase signaling (Childers, 1991; Howlett, 1995). Agonism of these receptors likewise results 
in similar behavioral outcomes; including analgesia, sedation, and reward/reinforcement. Interestingly, a growing body of literature illustrates a functional connection between these two neuro-modulatory systems. Evidencing this, CB administration increases endogenous opioid levels in the
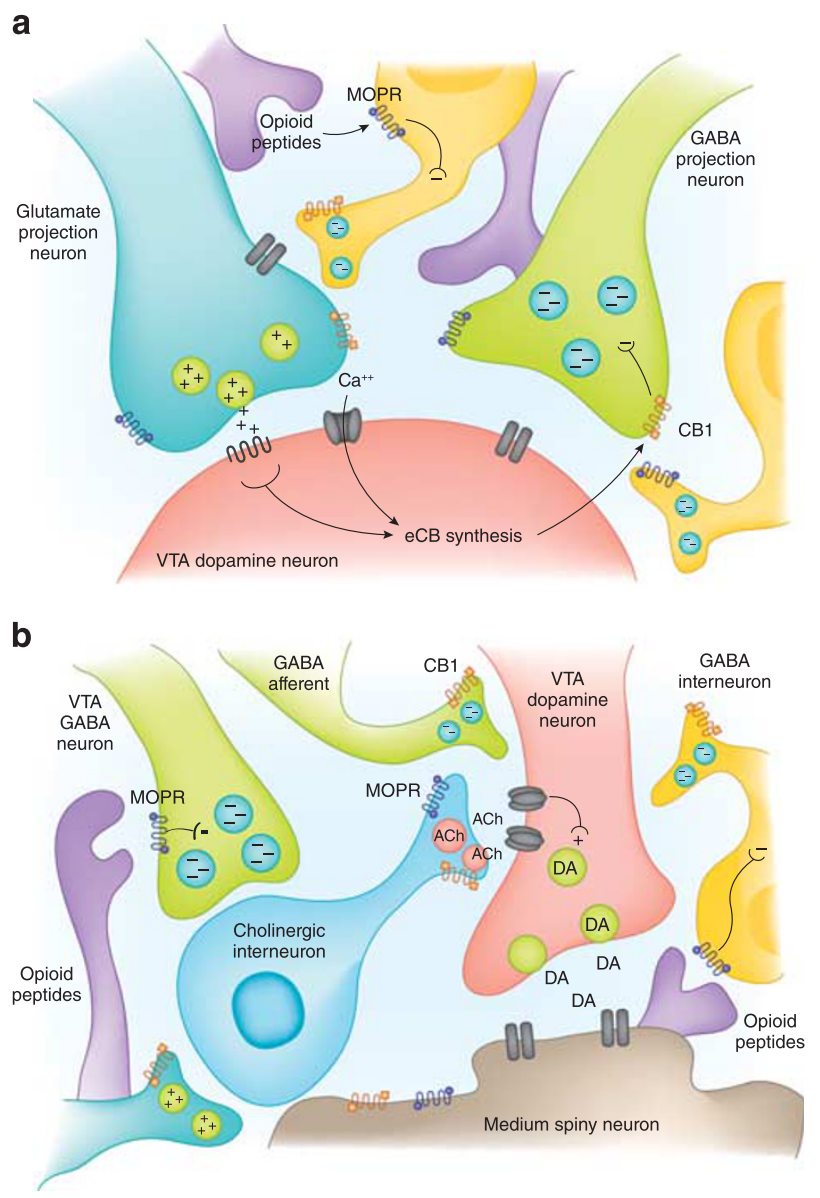

Figure 1. Schematic of proposed $\mathrm{eCB}$ and opioid interaction with the mesolimbic dopamine system in the ventral tegmental area and the nucleus accumbens. (a) Glutamatergic and GABAergic terminals of the ventral tegmental area (VTA) express mu opioid receptors (MOPR) and cannabinoid type-1 receptors (CB1). Glutamatergic activation of VTA dopamine (DA) neurons likely promotes synthesis and 'on demand' release of eCBs, which diffuse out of the post-synaptic cell and bind to CB1 to further disinhibit DA release via presynaptic GABA inhibition. Likewise, MOPR agonists (exogenous or endogenous opioid peptides) disinhibit VTA DA cells through inhibition of GABA neurons, which synapse on VTA DA cells or glutamate projections neurons. (b) NAc DA release can occur independently of VTA DA cell body excitation. The VTA sends GABAergic projections to the NAc, which synapse of cholinergic interneurons, inhibiting excitatory cholinergic (ACh) input onto DA terminals. CB1 or MOPR-mediated inhibition of these GABA cells may disinhibit ACh release, resulting in DA terminal stimulation. However, ACh interneurons express MOPR and CB1, suggesting that direct opioid or eCB inhibition of these cells may decrease DA concentration in the NAc. Glutamatergic and GABAergic terminals in the NAc may also directly modulate DA activity. NAc Glutamate and GABA cells express MOPR and/or CB1. Thus, CB1 or MOPR agonism of GABA inputs to NAc DA terminals could enhance DA release, while CB1 or MOPR-induced inhibition of glutamatergic inputs may dampen NAc DA release.
NAc (Valverde et al, 2001), and, reciprocally, opioid administration increases eCB levels (Caille et al, 2007). Further, chronic administration of either opioid or CB drugs results in cross tolerance (Newman et al, 1974), as well as alterations in receptor density and activation (Fattore et al, 2007). The mechanism underlying this functional interaction remains unclear, however, one possible explanation is interaction between receptors. CB1 and MOPR are similarly distributed throughout the brain, including regions subserving reward and reinforcement. Indeed, $\mathrm{CB} 1$ and MOPR co-localize on GABA neurons of the NAc (Pickel et al, 2004). Co-localization may result in the formation of heterodimers. Data suggest that in the NAc, $\mathrm{CB} 1$ and MOPR may heterodimerize and stimulation of these receptor complexes can cause synergistic inhibition of GABA release (Schoffelmeer et al, 2006). However, additional research is necessary to determine the extent to which this mechanism functions in vivo. For more in-depth review of opioid-eCB interactions, see reviews by Parolaro et al (2010); Robledo et al (2008); Vigano et al (2005).

Similarly, MOPR and CB1 functionally interact to mediate reward and reinforcement. MOPR knockout or antagonism (via systemic administration of naloxone) blocks CB-induced CPP (Braida et al, 2001a; Ghozland et al, 2002), while CB1 knockout or systemic rimonabant administration blocks the acquisition of opioid CPP or self-administration (Ledent et al, 1999; Martin et al, 2000; Navarro et al, 2001; 2004). Additionally, THC self-administration is attenuated by naloxone (Braida et al, 2001b; Justinova et al, 2004), and rimonabant blocks heroin self-administration (Caille and Parsons, 2005). These effects may be reliant on the ability of these systems to modulate mesolimbic DA (but see Caille and Parsons (2005)). In support of this, THC-induced DA release in the NAc is attenuated by systemic or intra-VTA MOPR antagonism (Chen et al, 1990; Tanda et al, 1997). However, heroin-induced enhancement of NAc DA concentrations was not diminished by systemic rimonabant (Tanda et al, 1997). Interestingly, MOPR antagonism does not affect THC-induced VTA DA cell firing (French, 1997), and CB1 antagonism does not affect activation of midbrain DA cells induced by morphine (Melis et al, 2000). These data suggest that interaction between opioid and $\mathrm{eCB}$ systems primarily in the NAc works to augment mesolimbic DA. See Figure 1; Table 1 for summary of neurotransmitter system interactions.

\section{CRITICAL ROLES FOR DA AND ENDOGENOUS OPIOIDS IN FOOD REWARD}

Food acts as a potent natural reward/reinforcer. Food seeking and consumption is sustained not only by metabolic need, but also by motivation for food and food's hedonic properties, which rely on DA and opioid systems. Several studies show that DAergic antagonism or lesions of the mesolimbic system attenuate food-seeking and operant responding for food/food-associated cues, but do not abolish feeding (Baldo et al, 2002; Cousins and Salamone, 1994; 
TABLE 1 Interactions between Endocannabinoid, Dopamine, and Opioid Systems

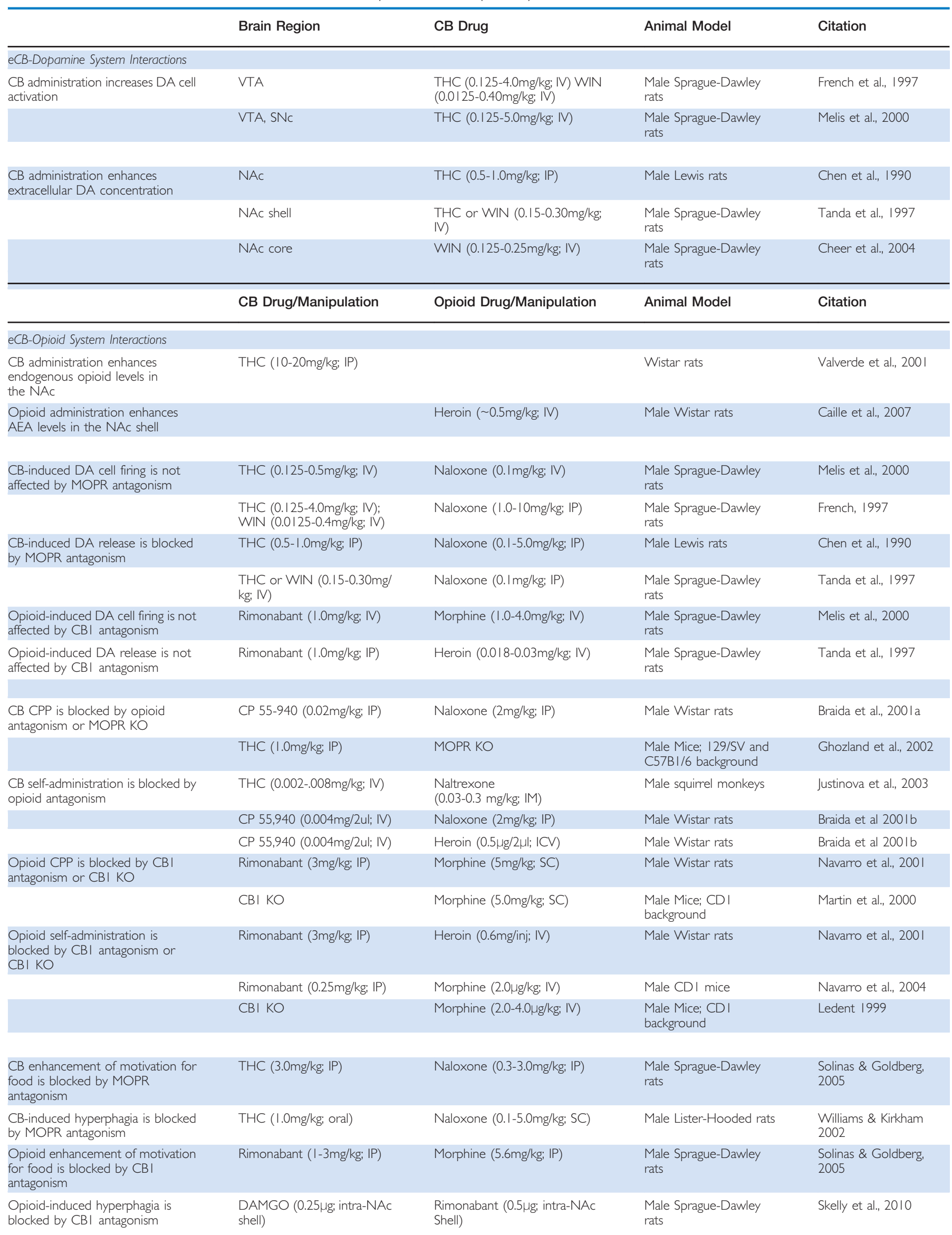






Koob et al, 1978). Moreover, DA depletion or antagonism spares the orofacial liking response to sucrose (Treit and Berridge, 1990). Thus, while mesolimbic DA mediates the effort exerted to obtain food, it does not mediate food's hedonic properties. Conversely, MOPR antagonism decreases food intake while MOPR agonism enhances food consumption (Bodnar, 2015). Interestingly, opioid antagonists preferentially attenuate intake of highly palatable food (eg, foods that are sweet or high in fat) (Yeomans and Gray, 1996), suggesting that MOPR signaling mediates the hedonic properties of food. Furthermore, in specific subregions of the NAc shell ('hotspots'), pharmacological stimulation of MOPR, DOPR, or KOPR enhances orofacial liking responses to sucrose (Castro and Berridge, 2014). Barbano et al (2009) found that systemic naloxone only decreases food intake in sated, but not hungry rats, and similarly reduces the effort rats are willing to exert for palatable food reinforcers. However, administration of the DA receptor antagonist flupenthixol attenuates how hard an animal will work for palatable food but does not affect food intake, suggesting that DA mediates the cost-benefit calculation of performing an action to obtain a reinforcer, but not necessarily hedonic value. Therefore, DA and endogenous opioids signal distinct facets of food reward and reinforcement (for a recent comprehensive review, see Baldo et al (2013).

\section{eCBs AND FOOD REWARD}

Stimulation of the eCB system promotes food reward and reinforcement partly through action within mesolimbic regions (Di Marzo and Matias, 2005). In 1975, Abel (1975) first documented the ability of cannabis to enhance appetite, especially for sweet foods. Since then, animal studies have shown that THC enhances food intake in sated rats (Williams et al, 1998) and increases the motivation to obtain food reinforcers (Solinas and Goldberg, 2005). Importantly, these effects are blocked by pretreatment with either $\mathrm{CB} 1$ or MOPR antagonists, suggesting a role for both the eCB and opioid systems in the motivation to work for food reinforcers (Solinas and Goldberg, 2005). These effects are likely due to the ability of THC to increase the hedonic properties of food, as THC enhances orofacial 'liking' reactions to sucrose and decreases aversive reactions to bitter quinine solutions (Jarrett et al, 2005, 2007). These effects are similarly blocked by CB1 receptor antagonism.

eCBs also modulate food reward and reinforcement. IntraNAc shell administration of 2-AG enhances food intake (Kirkham et al, 2002), as does systemic and intra-NAc delivery of AEA (Hao et al, 2000; Mahler et al, 2007). Furthermore, infusion of AEA into NAc shell hotspots enhances 'liking' reactions to sucrose solutions (Mahler et al, 2007). In support of a role for AEA in food reward, Williams and Kirkham $(1999,2002)$ found that systemic delivery of AEA results in significant over eating in sated rats, and this is blocked by pretreatment with rimonabant or naloxone, but not by CB2 antagonism. AEA-induced hyperphagia is not affected by the serotonin agonist dexfenfluramine, leading the authors to conclude that eCB signaling promotes feeding through enhancing food reward rather than inhibiting serotonergic satiety mechanisms (Williams and Kirkham, 2002), but see Thompson et al (2016). Indeed, rats readily develop a CPP for palatable foods, and this CPP is enhanced by intra-cranial AEA and blocked by intra-cranial CB1 receptor antagonism (Mendez-Diaz et al, 2012). However, pharmacological inhibition of AEA with VDM11 does not increase food intake, suggesting that endogenous AEA may be insufficient to drive food consumption (Chambers et al, 2004). Though transgenic mice with selectively reduced forebrain 2-AG levels, do not develop a CPP for palatable food, they do develop a CPP for cocaine (Wei et al, 2016), evidencing a role for endogenous 2-AG in palatable food reward.

Disruption of eCB signaling via $\mathrm{CB} 1$ receptor antagonism disturbs food reward and reinforcement. CB1 receptor antagonist administration or CB1 receptor knockout reduces the intake of food and sweet solutions (Arnone et al, 1997; Di Marzo and Matias, 2005; Thornton-Jones et al, 2005), and $\mathrm{CB} 1$ receptor antagonists reduce self-administration of palatable food in both food restricted and sated rats, suggesting a role in the hedonic properties of food (Fois 
et al, 2016). CB1 receptor antagonism also diminishes how hard an animal is willing to work for a food reinforcer (Solinas and Goldberg, 2005), although this could also stem from a lessened hedonic impact of food reinforcers, decreasing their value. Indeed, systemic rimonabant or CB1 receptor knockout abolishes the ability of conditioned food reward to mitigate acoustic startle, while treatment with WIN enhances 'pleasure attenuated startle' (Friemel et al, 2014). Similarly CB1 knockout mice have attenuated motivation for sucrose and exhibit a lessened sucrose preference (Sanchis-Segura et al, 2004). Interestingly, Skelly et al (2010) found that intra-NAc shell delivery of WIN or rimonabant alone had no affect on the consumption of highly palatable food, however, intra-NAc DAMGO enhanced food consumption and this enhancement was exacerbated by WIN and abolished by rimonabant. These data support a relationship between NAc CB1 and MOPR signaling upon the facilitation of food hedonics.

The role of eCB signaling in food reward and reinforcement suggests that this system may be an effective target for the treatment of eating disorders, such as binge eating disorder (BED). BED is characterized by episodes of compulsive overconsumption of highly palatable food (ie, binges) with subsequent distress. Human studies show that individuals with $\mathrm{BED}$ have enhanced craving for palatable food reinforcers (Joyner et al, 2015), which is matched by augmented DA signaling in response to food related stimuli (Wang et al, 2011). However, BED sufferers report decreased pleasure following eating (Klatzkin et al, 2016). These data suggest similarities between drug addiction and binge eating, such as an enhanced cue-induced DA response, increased craving, and decreased pleasure produced by ingestion. In an animal model of BED, experimental rats exhibited decreased DA receptor number and enhanced MOPR levels in the striatum, compared to controls (Heal et al, 2017), suggesting pathological function of these systems. The eCB system is similarly implicated in BED. Women with BED have elevated plasma AEA levels (Monteleone et al, 2005), which could lead to enhanced DAergic reactivity to food stimuli. Indeed, in rat models, rimonabant dose dependently reduces binge eating (Scherma et al, 2013) and also decreases palatable foodinduced NAc DA release (Melis et al, 2007). Similar results supported the use of rimonabant as a weight loss drug in human clinical trials. However, rimonabant administration resulted in depressed mood and anxiety, making the drug not well suited as a therapeutic (Christensen et al, 2007). Both the intended and side effects may be due to rimonabant's inhibition of mesolimbic DA signaling. Therefore, $\mathrm{CB}$ drugs capable of reducing DAergic response to palatable food without globally dampening DA signaling could provide treatment for BED. For example, the CB1 receptor antagonist SM-11, which attenuates VTA-NAc DA cell single spiking and burst activity induced by WIN administration, but does not affect baseline DAergic activity (Fois et al, 2016).

\section{CONCLUSIONS AND FUTURE DIRECTIONS}

In summary, the vast majority of research supports a role for eCB signaling in reward and reinforcement. Administration of $\mathrm{CB}$ drugs produces reward and reinforcement in both human users and in animal models. However, future research should work to improve the face validity of rodent models of CB self-administration through better modeling of human cannabis use with attention to the route of administration and chemical components of the CB drugs utilized. However, a role for endogenous activity of eCBs in reward remains unclear. Additional investigation utilizing neutral CB1 antagonists along with the development of tools for opto- and chemo-genetic targeting of $\mathrm{eCB}$ machinery will help to elucidate $\mathrm{eCB}$ function. Further, $\mathrm{CB}$ reward and reinforcement are blocked by MOPR antagonism, demonstrating a critical interaction between these systems in both hedonia and motivation. This relationship may be due to $\mathrm{CB} 1$ and MOPR interaction in mesolimbic regions such as the NAc, but further study is necessary to explore these mechanisms in vivo and their role in behavior.

A wide body of evidence indicates that $\mathrm{eCB}$ signaling is integral for food reward and food-maintained behavior. Exogenous CBs, like THC, increase food intake, enhance the amount of work an organism will perform for food, and augment CPP and orofacial liking reactions for palatable food. eCBs likely regulate food reward and reinforcement through interaction with DA and opioid systems in the VTA and NAc. MOPR antagonism blocks CB-induced enhancement of food seeking and hyperphagia, suggesting that endogenous opioid system activation underlies CB-induced food reward/reinforcement. Reciprocally, opioid-induced increases in food intake are blocked by CB1 antagonism, suggesting therapeutic potential for CBs in the treatment of eating disorders. However, with the failure of rimonabant there are currently no $\mathrm{CB}$ pharmacotherapies for eating disorders, emphasizing the need to develop $\mathrm{CB1}$ receptor antagonists without detrimental side effects. Likewise, the mechanism by which opioid and $\mathrm{eCB}$ systems interact to in eating disorders merits further investigation, with particular attention to gender differences. Sufferers of eating disorders are predominantly female (Hudson et al, 2007), however, investigations into eCB-opioid-DA interactions have all been performed in male rats. Altogether, future investigations should work to examine how these systems work together to mediate reward/reinforcement and how pathological interactions may contribute to psychiatric disorders.

\section{FUNDING AND DISCLOSURE}

Funding was provided by NIH grants DA039690 to JMW and DA022340/DA042595 to JFC. The authors declare no conflict of interest.

\section{REFERENCES}

Abel EL (1975). Cannabis: effects on hunger and thirst. Behav Biol 15: 255-281. 
Acquas E, Di Chiara G (1994). D1 receptor blockade stereospecifically impairs the acquisition of drug-conditioned place preference and place aversion. Behav Pharmacol 5: 555-569.

Alger BE (2002). Retrograde signaling in the regulation of synaptic transmission: focus on endocannabinoids. Prog Neurobio/ 68: 247-286.

Arnold JC, Hunt GE, McGregor IS (2001). Effects of the cannabinoid receptor agonist CP 55,940 and the cannabinoid receptor antagonist SR 141716 on intracranial self-stimulation in Lewis rats. Life Sci 70: 97-108.

Arnone M, Maruani J, Chaperon F, Thiebot MH, Poncelet M, Soubrie P et al (1997). Selective inhibition of sucrose and ethanol intake by SR 141716, an antagonist of central cannabinoid (CB1) receptors. Psychopharmacology 132: 104-106.

Atwood BK, Mackie K (2010). CB2: a cannabinoid receptor with an identity crisis. Br J Pharmacol 160: 467-479.

Baldo BA, Pratt WE, Will MJ, Hanlon EC, Bakshi VP, Cador M (2013). Principles of motivation revealed by the diverse functions of neuropharmacological and neuroanatomical substrates underlying feeding behavior. Neurosci Biobehav Rev 37: 1985-1998.

Baldo BA, Sadeghian K, Basso AM, Kelley AE (2002). Effects of selective dopamine D1 or D2 receptor blockade within nucleus accumbens subregions on ingestive behavior and associated motor activity. Behav Brain Res 137: 165-177.

Barbano MF, Le Saux M, Cador M (2009). Involvement of dopamine and opioids in the motivation to eat: influence of palatability, homeostatic state, and behavioral paradigms. Psychopharmacology 203: 475-487

Berridge KC, Robinson TE (1998). What is the role of dopamine in reward: hedonic impact, reward learning, or incentive salience? Brain Res Brain Res Rev 28: 309-369.

Bodnar RJ (2015). Endogenous opioids and feeding behavior: a decade of further progress (2004-2014). A Festschrift to Dr. Abba Kastin. Peptides 72: 20-33.

Bozarth MA, Wise RA (1981). Intracranial self-administration of morphine into the ventral tegmental area in rats. Life Sci 28: 551-555

Braida D, Pozzi M, Cavallini R, Sala M (2001a). Conditioned place preference induced by the cannabinoid agonist CP 55,940: interaction with the opioid system. Neuroscience 104: 923-926.

Braida D, Pozzi M, Parolaro D, Sala M (2001b). Intracerebral self-administration of the cannabinoid receptor agonist CP 55,940 in the rat: interaction with the opioid system. Eur J Pharmacol 413: 227-234.

Brauer LH, De Wit H (1997). High dose pimozide does not block amphetamineinduced euphoria in normal volunteers. Pharmacol Biochem Behav 56: 265-272.

Brischoux F, Chakraborty S, Brierley DI, Ungless MA (2009). Phasic excitation of dopamine neurons in ventral VTA by noxious stimuli. Proc Natl Acad Sci USA 106: 4894-4899.

Bromberg-Martin ES, Matsumoto M, Hikosaka O (2010). Dopamine in motivational control: rewarding, aversive, and alerting. Neuron 68: 815-834.

Brown HD, McCutcheon JE, Cone JJ, Ragozzino ME, Roitman MF (2011). Primary food reward and reward-predictive stimuli evoke different patterns of phasic dopamine signaling throughout the striatum. Eur J Neurosci 34: 1997-2006.

Budygin EA, Park J, Bass CE, Grinevich VP, Bonin KD, Wightman RM (2012). Aversive stimulus differentially triggers subsecond dopamine release in reward regions. Neuroscience 201: 331-337.

Caille S, Alvarez-Jaimes L, Polis I, Stouffer DG, Parsons LH (2007). Specific alterations of extracellular endocannabinoid levels in the nucleus accumbens by ethanol, heroin, and cocaine self-administration. J Neurosci 27: 3695-3702.

Caille S, Parsons LH (2005). Cannabinoid modulation of opiate reinforcement through the ventral striatopallidal pathway. Neuropsychopharmacology 31: 804-813.

Castro DC, Berridge KC (2014). Opioid hedonic hotspot in nucleus accumbens shell: mu, delta, and kappa maps for enhancement of sweetness 'liking' and 'wanting'. J Neurosci 34: 4239-4250.

Chambers AP, Sharkey KA, Koopmans HS (2004). Cannabinoid (CB)1 receptor antagonist, AM 251, causes a sustained reduction of daily food intake in the rat. Physiol Behav 82: 863-869.

Charlety PJ, Grenhoff J, Chergui K, la Chapelle De B, Buda M, Svensson TH et al (1991). Burst firing of mesencephalic dopamine neurons is inhibited by somatodendritic application of kynurenate. Acta Physiol Scand 142: 105-112.

Cheer JF, Marsden CA, Kendall DA, Mason R (2000). Lack of response suppression follows repeated ventral tegmental cannabinoid administration: an in vitro electrophysiological study. Neuroscience 99: 661-667.

Cheer JF, Wassum KM, Heien MLAV, Phillips PEM, Wightman RM (2004). Cannabinoids enhance subsecond dopamine release in the nucleus accumbens of awake rats. J Neurosci 24: 4393-4400.

Cheer JF, Wassum KM, Sombers LA, Heien MLAV, Ariansen JL, Aragona BJ et al (2007). Phasic dopamine release evoked by abused substances requires cannabinoid receptor activation. J Neurosci 27: 791-795.
Chefer VI, Backman CM, Gigante ED, Shippenberg TS (2013). Kappa opioid receptors on dopaminergic neurons are necessary for kappa-mediated place aversion. Neuropsychopharmacology 38: 2623-2631.

Chen D-J, Gao M, Gao F-F, Su Q-X, Wu J (2017). Brain cannabinoid receptor 2: expression, function and modulation. Acta Pharmacol Sin 38: 312-316.

Chen JP, Paredes W, Li J, Smith D, Lowinson J, Gardner EL (1990). Delta 9-tetrahydrocannabinol produces naloxone-blockable enhancement of presynaptic basal dopamine efflux in nucleus accumbens of conscious, freely-moving rats as measured by intracerebral microdialysis. Psychopharmacology 102: 156-162.

Chen M, Zhao Y, Yang H, Luan W, Song J, Cui D et al (2015). Morphine disinhibits glutamatergic input to VTA dopamine neurons and promotes dopamine neuron excitation. Elife 4 (doi:10.7554/eLife.09275).

Childers SR (1991). Opioid receptor-coupled second messenger systems. Life Sci 48: 1991-2003.

Christensen R, Kristensen PK, Bartels EM, Bliddal H, Astrup A (2007). Efficacy and safety of the weight-loss drug rimonabant: a meta-analysis of randomised trials. Lancet 370: 1706-1713.

Church WH, Justice JB, Byrd LD (1987). Extracellular dopamine in rat striatum following uptake inhibition by cocaine, nomifensine and benztropine. Eur J Pharmacol 139: 345-348.

Cousins MS, Salamone JD (1994). Nucleus accumbens dopamine depletions in rats affect relative response allocation in a novel cost/benefit procedure. Pharmacol Biochem Behav 49: 85-91.

Daniel M, Martin AD, Carter J (1992). Opiate receptor blockade by naltrexone and mood state after acute physical activity. Br J Sports Med 26: 111-115.

De Luca MA, Bimpisidis Z, Melis M, Marti M, Caboni P, Valentini V et al (2015). Stimulation of in vivo dopamine transmission and intravenous self-administration in rats and mice by JWH-018, a Spice cannabinoid. Neuropharmacology 99: 705-714.

De Luca MA, Valentini V, Bimpisidis Z, Cacciapaglia F, Caboni P, Di Chiara G (2014). Endocannabinoid 2-arachidonoylglycerol self-administration by Sprague-Dawley rats and stimulation of in vivo dopamine transmission in the nucleus accumbens shell. Front Psychiatry 5: 140.

Deroche-Gamonet V, Le Moal M, Piazza PV, Soubrie P (2001). SR141716, a CB1 receptor antagonist, decreases the sensitivity to the reinforcing effects of electrical brain stimulation in rats. Psychopharmacology 157: 254-259.

Devane WA, Hanus L, Breuer A, Pertwee RG (1992). Isolation and structure of a brain constituent that binds to the cannabinoid receptor. Science 258: 1946-1949.

Di Chiara G, Bassareo V, Fenu S, De Luca MA, Spina L, Cadoni C et al (2004). Dopamine and drug addiction: the nucleus accumbens shell connection. Neuropharmacology 47: 227-241.

Di Giannuario A, Pieretti S (2000). Nociceptin differentially affects morphine-induced dopamine release from the nucleus accumbens and nucleus caudate in rats. Peptides 21: 1125-1130.

Di Marzo V, Matias I (2005). Endocannabinoid control of food intake and energy balance. Nat Neurosci 8: 585-589.

Dobi A, Margolis EB, Wang H-L, Harvey BK, Morales M (2010). Glutamatergic and nonglutamatergic neurons of the ventral tegmental area establish local synaptic contacts with dopaminergic and nondopaminergic neurons. I Neurosci 30: 218-229.

Dreyer JK, Herrik KF, Berg RW, Hounsgaard JD (2010). Influence of phasic and tonic dopamine release on receptor activation. J Neurosci 30: 14273-14283.

Engberg G, Kling Petersen T, Nissbrandt H (1993). GABAB-Receptor activation alters the firing pattern of dopamine neurons in the rat substantia nigra. Synapse 15: 229-238.

Ettenberg A, Camp CH (1986a). A partial reinforcement extinction effect in water-reinforced rats intermittently treated with haloperidol. Pharmacol Biochem Behav 25: 1231-1235.

Ettenberg A, Camp CH (1986b). Haloperidol induces a partial reinforcement extinction effect in rats: implications for a dopamine involvement in food reward. Pharmacol Biochem Behav 25: 813-821.

Ettenberg A, Pettit HO, Bloom FE, Koob GF (1982). Heroin and cocaine intravenous self-administration in rats: mediation by separate neural systems. Psychopharmacology 78: 204-209

Fattore L, Cossu G, Martellotta CM, Fratta W (2001). Intravenous self-administration of the cannabinoid CB1 receptor agonist WIN 55,212-2 in rats. Psychopharmacology 156: 410-416.

Fattore L, Vigano D, Fadda P, Rubino T, Fratta W, Parolaro D (2007). Bidirectional regulation of mu-opioid and $\mathrm{CB} 1$-cannabinoid receptor in rats self-administering heroin or WIN 55,212-2. Eur J Neurosci 25: 2191-2200.

Fields HL, Margolis EB (2015). Understanding opioid reward. Trends Neurosci 38 : 217-225. 
Fois GR, Fattore L, Murineddu G, Salis A, Pintore G, Asproni B et al (2016). The novel cannabinoid antagonist SM-11 reduces hedonic aspect of food intake through a dopamine-dependent mechanism. Pharmacol Res 113: 108-115.

Fountain SB, Rowan JD, Ting YL (1990). Threshold procedures for assessing the impact of agents on brain reward systems. Neurotoxicol Teratol 12: 469-475.

French ED (1997). delta9-Tetrahydrocannabinol excites rat VTA dopamine neurons through activation of cannabinoid CB1 but not opioid receptors. Neurosci Lett 226: 159-162.

French ED, Dillon K, Wu X (1997). Cannabinoids excite dopamine neurons in the ventral tegmentum and substantia nigra. NeuroReport 8: 649-652.

Friemel CM, Zimmer A, Schneider M (2014). The CB1 receptor as an important mediator of hedonic reward processing. Neuropsychopharmacology 39: 2387-2396.

Fusco FR, Martorana A, Giampà C, De March Z, Farini D, D'Angelo V et al (2004). Immunolocalization of CB 1receptor in rat striatal neurons: A confocal microscopy study. Synapse 53: 159-167

Galiègue S, Mary S, Marchand J, Dussossoy D, Carrière D, Carayon P et al (1995). Expression of central and peripheral cannabinoid receptors in human immune tissues and leukocyte subpopulations. Eur J Biochem 232: 54-61.

Gantz SC, Bean BP (2017). Cell-autonomous excitation of midbrain dopamine neurons by endocannabinoid-dependent lipid signaling. Neuron 93: 1375-1387.e2

Gardner E (2005). Endocannabinoid signaling system and brain reward: emphasis on dopamine. Pharmacol Biochem Behav 81: 263-284.

Gardner E, Bi G-H, Thakur G, Makriyannis A, Seltzman HH, He X-H et al (2016). Preclinical evaluation of neutral cannabinoid $\mathrm{CB} 1$ receptor antagonists and cannabinoid CB1 receptor negative allosteric modulators for treating drug addiction. Int J Neuropsychopharmacol 19(Suppl 1): 3.

Gentry RN, Lee B, Roesch MR (2016). Phasic dopamine release in the rat nucleus accumbens predicts approach and avoidance performance. Nat Commun 7: 13154

Gessa GL, Melis M, Muntoni AL, Diana M (1998). Cannabinoids activate mesolimbic dopamine neurons by an action on cannabinoid CB1 receptors. Eur J Pharmacol 341: 39-44.

Ghozland S, Matthes HWD, Simonin F, Filliol D, Kieffer BL, Maldonado R (2002). Motivational effects of cannabinoids are mediated by mu-opioid and kappa-opioid receptors. J Neurosci 22: 1146-1154.

Gobbi G, Bambico FR, Mangieri R, Bortolato M, Campolongo P, Solinas M et al (2005). Antidepressant-like activity and modulation of brain monoaminergic transmission by blockade of anandamide hydrolysis. Proc Natl Acad Sci USA 102: $18620-18625$.

Gong J-P, Onaivi ES, Ishiguro H, Liu Q-R, Tagliaferro PA, Brusco A et al (2006). Cannabinoid CB2 receptors: immunohistochemical localization in rat brain. Brain Res 1071: 10-23.

Grace AA (1991). Phasic versus tonic dopamine release and the modulation of dopamine system responsivity: a hypothesis for the etiology of schizophrenia. Neuroscience 41: 1-24.

Hao S, Avraham Y, Mechoulam R, Berry EM (2000). Low dose anandamide affects food intake, cognitive function, neurotransmitter and corticosterone levels in diet-restricted mice. Eur J Pharmacol 392: 147-156.

Heal DJ, Hallam M, Prow M, Gosden J, Cheetham S, Choi YK et al (2017). Dopamine and mu-opioid receptor dysregulation in the brains of binge-eating female rats-possible relevance in the psychopathology and treatment of binge-eating disorder. J Psychopharmacol 31: 770-783.

Herkenham M, Lynn AB, Johnson MR, Melvin LS, de Costa BR, Rice KC (1991). Characterization and localization of cannabinoid receptors in rat brain: a quantitative in vitro autoradiographic study. J Neurosci 11: 563-583.

Hernandez L, Hoebel BG (1988a). Food reward and cocaine increase extracellular dopamine in the nucleus accumbens as measured by microdialysis. Life Sci $\mathbf{4 2}$ 1705-1712.

Hernandez L, Hoebel BG (1988b). Feeding and hypothalamic stimulation increase dopamine turnover in the accumbens. Physiol Behav 44: 599-606.

Hnasko TS, Sotak BN, Palmiter RD (2005). Morphine reward in dopaminedeficient mice. Nature 438: 854-857

Horvitz JC (2000). Mesolimbocortical and nigrostriatal dopamine responses to salient non-reward events. Neuroscience 96: 651-656.

Howlett AC (1995). Pharmacology of cannabinoid receptors. Annu Rev Pharmacol Toxicol 35: 607-634

Hudson Jl, Hiripi E, Pope HGJ, Kessler RC (2007). The prevalence and correlates of eating disorders in the National Comorbidity Survey Replication. Biol Psychiatry 61: 348-358.

Ikemoto S (2007). Dopamine reward circuitry: two projection systems from the ventral midbrain to the nucleus accumbens-olfactory tubercle complex. Brain Res Rev 56: 27-78.
Jarrett MM, Limebeer CL, Parker LA (2005). Effect of Delta9-tetrahydrocannabinol on sucrose palatability as measured by the taste reactivity test. Physiol Behav 86: 475-479.

Jarrett MM, Scantlebury J, Parker LA (2007). Effect of delta9-tetrahydrocannabinol on quinine palatability and AM251 on sucrose and quinine palatability using the taste reactivity test. Physiol Behav 90: 425-430.

Joyner MA, Gearhardt AN, White MA (2015). Food craving as a mediator between addictive-like eating and problematic eating outcomes. Eat Behav 19 98-101.

Justinova Z, Solinas M, Tanda G, Redhi GH, Goldberg SR (2005). The endogenous cannabinoid anandamide and its synthetic analog $R(+)$-methanandamide are intravenously self-administered by squirrel monkeys. J Neurosci 25: 5645-5650.

Justinova Z, Tanda G, Munzar P, Goldberg SR (2004). The opioid antagonist naltrexone reduces the reinforcing effects of Delta 9 tetrahydrocannabinol (THC) in squirrel monkeys. Psychopharmacology 173: 186-194.

Justinova Z, Tanda G, Redhi GH, Goldberg SR (2003). Self-administration of delta9tetrahydrocannabinol (THC) by drug naive squirrel monkeys. Psychopharmacology 169: 135-140.

Justinova Z, Yasar S, Redhi GH, Goldberg SR (2011). The endogenous cannabinoid 2-arachidonoylglycerol is intravenously self-administered by squirrel monkeys. J Neurosci 31: 7043-7048.

Katona I, Sperlágh B, Sík A, Käfalvi A, Vizi ES, Mackie K et al (1999). Presynaptically located $\mathrm{CB} 1$ cannabinoid receptors regulate GABA release from axon terminals of specific hippocampal interneurons. J Neurosci 19: 4544-4558.

Katsidoni V, Kastellakis A, Panagis G (2013). Biphasic effects of Delta9tetrahydrocannabinol on brain stimulation reward and motor activity. Int $J$ Neuropsychopharmacol 16: 2273-2284.

Kirkham TC, Williams CM, Fezza F, Di Marzo V (2002). Endocannabinoid levels in rat limbic forebrain and hypothalamus in relation to fasting, feeding and satiation: stimulation of eating by 2-arachidonoyl glycerol. Br J Pharmacol 136: 550-557.

Klatzkin RR, Gaffney S, Cyrus K, Bigus E, Brownley KA (2016). Stress-induced eating in women with binge-eating disorder and obesity. Biol Psychol (e-pub ahead of print).

Koob GF, Riley SJ, Smith SC, Robbins TW (1978). Effects of 6-hydroxydopamine lesions of the nucleus accumbens septi and olfactory tubercle on feeding, locomotor activity, and amphetamine anorexia in the rat. J Comp Physiol Psychol 92: 917-927.

Lalanne L, Ayranci G, Kieffer BL, Lutz P-E (2014). The kappa opioid receptor: from addiction to depression, and back. Front Psychiatry 5: 170.

Lammel S, Ion DI, Roeper J, Malenka RC (2011). Projection-specific modulation of dopamine neuron synapses by aversive and rewarding stimuli. Neuron 70: 855-862.

Laviolette SR, Nader K, van der Kooy D (2002). Motivational state determines the functional role of the mesolimbic dopamine system in the mediation of opiate reward processes. Behav Brain Res 129: 17-29.

Le Merrer J, Becker JAJ, Befort K, Kieffer BL (2009). Reward processing by the opioid system in the brain. Physiol Rev 89: 1379-1412.

Ledent C, Valverde O, Cossu G, Petitet F, Aubert JF, Beslot F et al (1999). Unresponsiveness to cannabinoids and reduced addictive effects of opiates in CB1 receptor knockout mice. Science 283: 401-404.

Lefever TW, Marusich JA, Antonazzo KR, Wiley JL (2014). Evaluation of WIN $55,212-2$ self-administration in rats as a potential cannabinoid abuse liability model. Pharmacol Biochem Behav 118: 30-35.

Leone P, Di Chiara G (1987). Blockade of D-1 receptors by SCH 23390 antagonizes morphine- and amphetamine-induced place preference conditioning. Eur J Pharmacol 135: 251-254.

Lepore M, Liu X, Savage V, Matalon D, Gardner EL (1996). Genetic differences in delta 9-tetrahydrocannabinol-induced facilitation of brain stimulation reward as measured by a rate-frequency curve-shift electrical brain stimulation paradigm in three different rat strains. Life Sci 58: PL365-PL372.

Lepore M, Vorel SR, Lowinson J, Gardner EL (1995). Conditioned place preference induced by delta 9-tetrahydrocannabinol: comparison with cocaine, morphine, and food reward. Life Sci 56: 2073-2080.

Lupica CR, Riegel AC (2005). Endocannabinoid release from midbrain dopamine neurons: a potential substrate for cannabinoid receptor antagonist treatment of addiction. Neuropharmacology 48: 1105-1116.

Mahler SV, Smith KS, Berridge KC (2007). Endocannabinoid hedonic hotspot for sensory pleasure: anandamide in nucleus accumbens shell enhances 'liking' of a sweet reward. Neuropsychopharmacology 32: 2267-2278.

Mallet PE, Beninger RJ (1998). Delta9-tetrahydrocannabinol, but not the endogenous cannabinoid receptor ligand anandamide, produces conditioned place avoidance. Life Sci 62: 2431-2439.

Mantz J, Thierry AM, Glowinski J (1989). Effect of noxious tail pinch on the discharge rate of mesocortical and mesolimbic dopamine neurons: selective activation of the mesocortical system. Brain Res 476: 377-381. 
Martellotta MC, Cossu G, Fattore L, Gessa GL, Fratta W (1998). Self-administration of the cannabinoid receptor agonist WIN 55,212-2 in drug-naive mice. Neuroscience 85: 327-330.

Martin M, Ledent C, Parmentier M, Maldonado R, Valverde O (2000). Cocaine, but not morphine, induces conditioned place preference and sensitization to locomotor responses in CB1 knockout mice. Eur J Neurosci 12: 4038-4046.

Mechoulam R, Ben-Shabat S, Hanus L, Ligumsky M, Kaminski NE, Schatz AR et al (1995). Identification of an endogenous 2-monoglyceride, present in canine gut, that binds to cannabinoid receptors. Biochem Pharmacol 50: 83-90.

Melis M, Frau R, Kalivas PW, Spencer S, Chioma V, Zamberletti E et al (2017). New vistas on cannabis use disorder. Neuropharmacology (e-pub ahead of print).

Melis M, Gessa GL, Diana M (2000). Different mechanisms for dopaminergic excitation induced by opiates and cannabinoids in the rat midbrain. Prog Neuropsychopharmacol Biol Psychiatry 24: 993-1006.

Melis M, Pistis M, Perra S, Muntoni AL, Pillolla G, Gessa GL (2004). Endocannabinoids mediate presynaptic inhibition of glutamatergic transmission in rat ventral tegmental area dopamine neurons through activation of CB1 receptors. J Neurosci 24: 53-62.

Melis T, Succu S, Sanna F, Boi A, Argiolas A, Melis MR (2007). The cannabinoid antagonist SR 141716A (Rimonabant) reduces the increase of extra-cellular dopamine release in the rat nucleus accumbens induced by a novel high palatable food. Neurosci Lett 419: 231-235.

Mendez-Diaz M, Rueda-Orozco PE, Ruiz-Contreras AE, Prospero-Garcia O (2012). The endocannabinoid system modulates the valence of the emotion associated to food ingestion. Addict Biol 17: 725-735.

Meyers C, Amick MA, Friedman JH (2010). Ice cream preference in Parkinson's disease. Med Health R/ 93: 91-92.

Monteleone P, Matias I, Martiadis V, De Petrocellis L, Maj M, Di Marzo V (2005). Blood levels of the endocannabinoid anandamide are increased in anorexia nervosa and in binge-eating disorder, but not in bulimia nervosa. Neuropsychopharmacology 30: 1216-1221.

Mora F, Rolls ET, Burton MJ (1975). Differential effects on self-stimulation and motor behaviour produced by microintracranial injections of a dopamine receptor blocking agent. Neurosci Lett 1:179-184.

Navarro M, Carrera MR, Fratta W, Valverde O, Cossu G, Fattore L et al (2001). Functional interaction between opioid and cannabinoid receptors in drug selfadministration. J Neurosci 21: 5344-5350.

Navarro M, Carrera MRA, Del Arco I, Trigo JM, Koob GF, Rodriguez de Fonseca F (2004). Cannabinoid receptor antagonist reduces heroin self-administration only in dependent rats. Eur J Pharmacol 501: 235-237.

Newman LM, Lutz MP, Domino EF (1974). Delta9-tetrahydrocannabinol and some CNS depressants: evidence for cross-tolerance in the rat. Arch Int Pharmacodyn Ther 207: 254-259.

Núñez E, Benito C, Pazos MR, Barbachano A, Fajardo O, González S et al (2004). Cannabinoid CB 2receptors are expressed by perivascular microglial cells in the human brain: an immunohistochemical study. Synapse 53: 208-213.

Olds J, Milner P (1954). Positive reinforcement produced by electrical stimulation of septal area and other regions of rat brain. J Comp Physiol Psychol 47: 419-427.

Oleson EB, Gentry RN, Chioma VC, Cheer JF (2012). Subsecond dopamine release in the nucleus accumbens predicts conditioned punishment and its successful avoidance. J Neurosci 32: 14804-14808.

Parker LA, Gillies T (1995). THC-induced place and taste aversions in Lewis and Sprague-Dawley rats. Behav Neurosci 109: 71-78.

Parolaro D, Rubino T, Vigano D, Massi P, Guidali C, Realini N (2010). Cellular mechanisms underlying the interaction between cannabinoid and opioid system. Curr Drug Targets 11: 393-405.

Pecina S (2005). Hedonic hot spot in nucleus accumbens shell: where do -opioids cause increased hedonic impact of sweetness? J Neurosci 25: 11777-11786.

Pickel VM, Chan J, Kash TL, Rodriguez JJ, Mackie K (2004). Compartment-specific localization of cannabinoid 1 (CB1) and mu-opioid receptors in rat nucleus accumbens. Neuroscience 127: 101-112.

Ramiro-Fuentes S, Ortiz O, Moratalla R, Fernandez-Espejo E (2010). Intraaccumbens rimonabant is rewarding but induces aversion to cocaine in cocaine-treated rats, as does in vivo accumbal cannabinoid CB1 receptor silencing: critical role for glutamate receptors. Neuroscience 167: 205-215.

Redgrave P, Prescott TJ, Gurney K (1999). Is the short-latency dopamine response too short to signal reward error? Trends Neurosci 22: 146-151.

Riegel AC, Lupica CR (2004). Independent presynaptic and postsynaptic mechanisms regulate endocannabinoid signaling at multiple synapses in the ventral tegmental area. J Neurosci 24: 11070-11078.

Robledo P, Berrendero F, Ozaita A, Maldonado R (2008). Advances in the field of cannabinoid-opioid cross-talk. Addict Biol 13: 213-224.

Robledo P, Maldonado-Lopez R, Koob GF (1992). Role of dopamine receptors in the nucleus accumbens in the rewarding properties of cocaine. Ann NY Acad Sci 654: 509-512.
Roitman MF (2004). Dopamine operates as a subsecond modulator of food seeking. J Neurosci 24: 1265-1271.

Roitman MF, Wheeler RA, Wightman RM, Carelli RM (2008). Real-time chemical responses in the nucleus accumbens differentiate rewarding and aversive stimuli. Nat Neurosci 11: 1376-1377.

Romo R, Schultz W (1990). Dopamine neurons of the monkey midbrain: contingencies of responses to active touch during self-initiated arm movements. J Neurophysio/ 63: 592-606.

Russo E, Guy GW (2006). A tale of two cannabinoids: the therapeutic rationale for combining tetrahydrocannabinol and cannabidiol. Med Hypotheses 66: 234-246.

Ryberg E, Larsson N, Sjögren S, Hjorth S, Hermansson N-O, Leonova J et al (2009). The orphan receptor GPR55 is a novel cannabinoid receptor. $\mathrm{Br} J$ Pharmacol 152: 1092-1101.

Salamone JD, Correa M (2002). Motivational views of reinforcement: implications for understanding the behavioral functions of nucleus accumbens dopamine. Behav Brain Res 137: 3-25.

Sanchis-Segura C, Cline BH, Marsicano G, Lutz B, Spanagel R (2004). Reduced sensitivity to reward in CB1 knockout mice. Psychopharmacology 176: 223-232.

Scherma M, Fattore L, Satta V, Businco F, Pigliacampo B, Goldberg SR et al (2013). Pharmacological modulation of the endocannabinoid signalling alters binge-type eating behaviour in female rats. Br J Pharmacol 169: 820-833.

Schindler CW, Scherma M, Redhi GH, Vadivel SK, Makriyannis A, Goldberg SR et al (2016). Self-administration of the anandamide transport inhibitor AM404 by squirrel monkeys. Psychopharmacology 233: 1867-1877.

Schoffelmeer ANM, Hogenboom F, Wardeh G, De Vries TJ (2006). Interactions between CB1 cannabinoid and mu opioid receptors mediating inhibition of neurotransmitter release in rat nucleus accumbens core. Neuropharmacology 51 : 773-781.

Schultz W (1998). Predictive reward signal of dopamine neurons. J Neurophysio/ 80: $1-27$.

Schultz W, Dayan P, Montague PR (1997). A neural substrate of prediction and reward. Science 275: 1593-1599.

Schultz W, Romo R (1987). Responses of nigrostriatal dopamine neurons to high-intensity somatosensory stimulation in the anesthetized monkey. J Neurophysio/ 57: 201-217.

Shippenberg TS, LeFevour A, Chefer VI (2008). Targeting endogenous mu- and delta-opioid receptor systems for the treatment of drug addiction. CNS Neurol Disord Drug Targets 7: 442-453.

Skelly MJ, Guy EG, Howlett AC, Pratt WE (2010). CB1 receptors modulate the intake of a sweetened-fat diet in response to mu-opioid receptor stimulation of the nucleus accumbens. Pharmacol Biochem Behav 97: 144-151.

Solinas M, Goldberg SR (2005). Motivational effects of cannabinoids and opioids on food reinforcement depend on simultaneous activation of cannabinoid and opioid systems. Neuropsychopharmacology 30: 2035-2045.

Spanagel R, Herz A, Shippenberg TS (1992). Opposing tonically active endogenous opioid systems modulate the mesolimbic dopaminergic pathway. Proc Natl Acad Sci USA 89: 2046-2050.

Sperlágh B, Windisch K, Andó RD, Vizi ES (2009). Neurochemical evidence that stimulation of CB1 cannabinoid receptors on GABAergic nerve terminals activates the dopaminergic reward system by increasing dopamine release in the rat nucleus accumbens. Neurochem Int 54: 452-457.

Sunsay C, Rebec GV (2008). Real-time dopamine efflux in the nucleus accumbens core during Pavlovian conditioning. Behav Neurosci 122: 358-367.

Swanson LW (1982). The projections of the ventral tegmental area and adjacent regions: a combined fluorescent retrograde tracer and immunofluorescence study in the rat. Brain Res Bull 9: 321-353.

Szabo B, Siemes S, Wallmichrath I (2002). Inhibition of GABAergic neurotransmission in the ventral tegmental area by cannabinoids. Eur $\mathrm{J}$ Neurosci 15: 2057-2061.

Szallasi A, Di Marzo V (2000). New perspectives on enigmatic vanilloid receptors. Trends Neurosci 23: 491-497.

Taber KH, Black DN, Porrino LJ, Hurley RA (2012). Neuroanatomy of dopamine: reward and addiction. J Neuropsychiatry Clin Neurosci 24: 1-4.

Taber MT, Zernig G, Fibiger HC (1998). Opioid receptor modulation of feedingevoked dopamine release in the rat nucleus accumbens. Brain Res 785: 24-30.

Tanda G (2016). Preclinical studies on the reinforcing effects of cannabinoids. A tribute to the scientific research of Dr. Steve Goldberg. Psychopharmacology 233: 1845-1866.

Tanda G, Munzar P, Goldberg SR (2000). Self-administration behavior is maintained by the psychoactive ingredient of marijuana in squirrel monkeys. Nat Neurosci 3: 1073-1074.

Tanda G, Pontieri FE, Di Chiara G (1997). Cannabinoid and heroin activation of mesolimbic dopamine transmission by a common mu1 opioid receptor mechanism. Science 276: 2048-2050. 
Thompson EE, Jagielo-Miller JE, Vemuri VK, Makriyannis A, McLaughlin PJ (2016). CB1 antagonism produces behaviors more consistent with satiety than reduced reward value in food-maintained responding in rats. J Psychopharmacol 30: 482-491.

Thompson T, Schuster CR (1964). Morphine self-administration, food-reinforced, and avoidance behaviors in rhesus monkeys. Psychopharmacologia 5: 87-94.

Thornton-Jones ZD, Vickers SP, Clifton PG (2005). The cannabinoid CB1 receptor antagonist SR141716A reduces appetitive and consummatory responses for food. Psychopharmacology 179: 452-460.

Treit D, Berridge KC (1990). A comparison of benzodiazepine, serotonin, and dopamine agents in the taste-reactivity paradigm. Pharmacol Biochem Behav 37: 451-456.

Tzschentke TM (2007). Measuring reward with the conditioned place preference (CPP) paradigm: update of the last decade. Addict Biol 12: 227-462.

Ungless MA, Argilli E, Bonci A (2010). Effects of stress and aversion on dopamine neurons: implications for addiction. Neurosci Biobehav Rev 35: 151-156.

Valjent E, Maldonado R (2000). A behavioural model to reveal place preference to delta 9-tetrahydrocannabinol in mice. Psychopharmacology 147: 436-438.

Valverde O, Noble F, Beslot F, Dauge V, Fournie-Zaluski MC, Roques BP (2001). Delta9-tetrahydrocannabinol releases and facilitates the effects of endogenous enkephalins: reduction in morphine withdrawal syndrome without change in rewarding effect. Eur J Neurosci 13: 1816-1824.

van Wolfswinkel L, van Ree JM (1985). Effects of morphine and naloxone on thresholds of ventral tegmental electrical self-stimulation. Naunyn Schmiedebergs Arch Pharmacol 330: 84-92.

Vigano D, Rubino T, Parolaro D (2005). Molecular and cellular basis of cannabinoid and opioid interactions. Pharmacol Biochem Behav 81: 360-368.

Vlachou S, Nomikos GG, Panagis G (2005). CB1 cannabinoid receptor agonists increase intracranial self-stimulation thresholds in the rat. Psychopharmacology 179: 498-508.

Vlachou S, Nomikos GG, Panagis G (2006). Effects of endocannabinoid neurotransmission modulators on brain stimulation reward. Psychopharmacology 188: 293-305.

Wang G-J, Geliebter A, Volkow ND, Telang FW, Logan J, Jayne MC et al (2011). Enhanced striatal dopamine release during food stimulation in binge eating disorder. Obesity 19: 1601-1608.
Wei D, Lee D, Li D, Daglian J, Jung K-M, Piomelli D (2016). A role for the endocannabinoid 2-arachidonoyl-sn-glycerol for social and high-fat food reward in male mice. Psychopharmacology 233: 1911-1919.

Williams CM, Kirkham TC (1999). Anandamide induces overeating: mediation by central cannabinoid (CB1) receptors. Psychopharmacology 143: 315-317.

Williams CM, Kirkham TC (2002). Reversal of delta 9-THC hyperphagia by SR141716 and naloxone but not dexfenfluramine. Pharmacol Biochem Behav 71: 333-340.

Williams CM, Rogers PJ, Kirkham TC (1998). Hyperphagia in pre-fed rats following oral delta9-THC. Physiol Behav 65: 343-346.

Wise RA, Rompre PP (1989). Brain dopamine and reward. Annu Rev Psychol 40: $191-225$.

Witkin JM, Statnick MA, Rorick-Kehn LM, Pintar JE, Ansonoff M, Chen Y et al (2014). The biology of Nociceptin/Orphanin FQ (N/OFQ) related to obesity, stress, anxiety, mood, and drug dependence. Pharmacol Ther 141: 283-299.

Xi Z-X, Peng X-Q, Li X, Song R, Zhang H-Y, Liu Q-R et al (2011). Brain cannabinoid CB2 receptors modulate cocaine's actions in mice. Nat Neurosci 14 1160-1166.

Yeomans MR, Gray RW (1996). Selective effects of naltrexone on food pleasantness and intake. Physiol Behav 60: 439-446.

Yorgason JT, Zeppenfeld DM, Williams JT (2017). Cholinergic interneurons underlie spontaneous dopamine release in nucleus accumbens. I Neurosci 37: 2086-2096.

Yoshida M, Yokoo H, Mizoguchi K, Kawahara H, Tsuda A, Nishikawa T et al (1992). Eating and drinking cause increased dopamine release in the nucleus accumbens and ventral tegmental area in the rat: measurement by in vivo microdialysis. Neurosci Lett 139: 73-76.

Zangen A (2006). Two brain sites for cannabinoid reward. J Neurosci 26: 4901-4907.

Zhang H-Y, Gao M, Liu Q-R, Bi G-H, Li X, Yang H-J et al (2014). Cannabinoid CB 2receptors modulate midbrain dopamine neuronal activity and dopamine-related behavior in mice. Proc Natl Acad Sci USA 111: E5007-E5015.

Zhang W, Yang HL, Song JJ, Chen M, Dong Y, Lai B et al (2015). DAMGO depresses inhibitory synaptic transmission via different downstream pathways of $\mu$ opioid receptors in ventral tegmental area and periaqueductal gray. Neuroscience 301: 144-154. 